\title{
Problems of new blood test
}

Washington

THE announcement last month by federal officials that a blood test for acquired immune deficiency syndrome (AIDS) will be available in six months has left unanswered a number of difficult questions, both practical and ethical. The need for a huge number of tests very quickly, concern in the homosexual community about confidentiality and uncertainties over just what a positive test result will signify for someone with no AIDS symptoms may make the introduction of the test far more difficult than first thought.

AIDS researchers and blood-bank officials were concerned last week that the companies involved with Dr Robert Gallo, the National Cancer Institute investigator who isolated the AIDS virus, HTLV-III, and who has developed the prototype test, do not have the capacity to manufacture and distribute the millions of tests that will be required each year. "Our interest is that nothing stand in the way of access to the reagents" for any company ready to

\section{Jumping guns?}

Perhaps from a sense of neglect by Dr Robert Gallo's isolation of the causative agent of AIDS and the development of the basis for a blood test, Cellular Products Inc. of Buffalo, New York, sent out the day after Gallo's announcement a press release with the headline: "AIDS TEST AVAILABLE FROM CELLULAR PRODUCTS".

Claiming that "HTLV' had been found in 80-90 per cent of patients with AIDS or certain pre-AIDS conditions, the document went on to note that the company had been performing tests for HTLV membrane antigen since January and would, within 90 days, have a test kit available. "Response from physicians to the idea of a test kit has been very promising", the statement said. "The suspected relationship between HTLV and AIDS warrants such testing."

It took an interview with the company's president and scientific director, Dr Richard Montagna, to discover that the test is not for HTLV-III, the virus just isolated by Gallo, but HTLV-I, and that the test is not, as stated in the press release, for membrane antigen but for antibody. Montagna said the $80-90$ per cent correlation they were finding was at a low dilution rate which, he acknowledged, also produced a large number of false positives.

Montagna said that "what we wanted to make people aware of is that we have been offering an HTLV test since the first of January. We certainly weren't trying to mislead anyone". He added: "We have to re-evaluate the whole thing now that we've seen Gallo's data." Stephen Budiansky produce the test, said Dr Peter Page, director of the American Red Cross Blood Services for the north-east region of the United States.

The US Public Health Service announced suddenly last week that it would accept applications - due in ten days - from companies interested in manufacturing the test. The announcement did not say whether the licence would be granted exclusively to a single company.

The two companies working with Gallo, Litton Bionetics and Biotechnology Research Laboratories, were both quickly able to produce test kits for HTLV-I after Gallo's isolation of that related virus, and expect to do as well with the virus now linked with AIDS. But according to Page, 12 million tests will be required each year just to screen the whole blood collected by the Red Cross. Several million more will be needed by the commercial blood industry, which supplies most plasma products, including factor VIII for haemophiliacs, used in the United States. Screening of high-risk groups - male homosexuals, intravenous drug users, haemophiliacs and Haitians - would take several million more tests.

Page hopes that everyone will be able to have the test at once, thus avoiding fights over which group deserves priority. There appears to be general agreement, nonetheless, that the most pressing need is for screening of the plasma products. The fact that the bulk comes from paid donors, that haemophiliacs require several treatments each month and that each treatment represents an exposure to a thousand donors, whose plasma is pooled to produce factor VIII concentrate, places the 12,000 haemophiliacs in the United States particularly at risk.

Next in priority would be whole blood collected in high-risk regions of the country, especially New York City and San Francisco. Although Red Cross officials say that their volunteer donors appear to be complying with pleas for members of highrisk groups not to give blood, several dozen cases of AIDS have been traced to wholeblood transfusions.

Abbott Laboratories has been mentioned by several researchers as a company likely to have the means to produce the HTLV-III test on a massive scale. Abbott supplies a test for hepatitis-B antigen that is currently run on every unit of blood. But mass production of the AIDS test poses special problems not shared with the hepatitis-B test. According to Cladd Stevens of the New York Blood Center, the AIDS test will use virus antigen to detect the presence of AIDS antibody in the blood, so that manufacturers must master Gallo's newly developed techniques for growing the virus.

Confidentiality, a recurring concern in the homosexual community, is sure to be
Natural selection

THE name of Stephen Gould has, since he and Niles Eldredge formulated the notion of punctuated equilibria in 1972, been dragged into the increasingly fashionable practice of arguing, mostly on specious grounds, that Darwin may have got evolution wrong. It is therefore a relief to be able to report that at the end of four hour-long lectures and a day-long seminar at Cambridge last week, Gould and eight invited discussants concluded that by and large, Darwin, who would not have known how to be specious, got it right.

Gould was in Cambridge to give the sixth annual Tanner lectures under the auspices of Clare Hall, and used the opportunity to incorporate into his already well known ideas on evolutionary processes some recent surprising insights into evolution at the molecular level. In the event, this was the only topic seriously to raise the temperature at the seminar, where eight panellists were invited to spend ten minutes each commenting on the issues raised by Gould before the discussion was thrown open to the other panellists and the floor.

In closing the meeting, Sir Peter Medawar observed with satisfaction that no theory, no matter how well established, can be considered exempt from Popperian challenge, and averred that nobody attending Gould's lectures could have left with his ideas unchanged.

Miranda Robertson

raised again when blood screening begins. Dr Roger Dodd, the National Red Cross official in charge of blood-transmissible disease programmes, thinks it likely that data gathered from AIDS testing will be handled much as hepatitis-B testing is now. A donor whose blood tested positive for AIDS would be informed by letter, an offer would be made to make the information available to the donor's physician and the donor would be entered on a confidential computer list of "deferred" donors, whose blood would not in future be accepted. Dodd said that the computer list would contain coded data indicating the reason for the deferment, but that access would be strictly controlled.

The situation may be further complicated because AIDS is a reportable disease. State health authorities are informed of donors whose blood is positive for syphilis, for example. The AIDS test may, however, escape this requirement because the test itself is not a definitive diagnosis of the disease.

Indeed, it is still unclear just what a positive test will signify. Jerome Groopman, of the Harvard Medical School, says that although studies so far suggest that everyone who has AIDS has antibody, it is far from certain that everyone with antibody will develop AIDS. "We're not going to know what to do about it except tell them not to give blood"', Page says. Stephen Budiansky 